Nordisk Tidsskrift for Kriminalvidenskab 2005

\title{
KRIMINALITETSFOREBYGGING OG POLITIROLLEN ${ }^{1}$
}

Av førsteamanuensis Paul Larsson

This paper describes what the Norwegian police mean by "crime prevention". No single definition covers the wide range of different activities and strategies that fall under this concept. Crime prevention strategies can, however, be roughly assigned to one of nine different categories, including: a) crime prevention through patrolling, detection and law enforcement (the legalistic perspective); b) community policing; c) police as a social service; d) campaigns of information and attitude; e) crime prevention on an individual level; f) the cooperative model; $g$ ) assistance concerning technical prevention (locks, alarms and keys); h) situational crime prevention; and i) problem-oriented policing (POP). The author argues that there are two main directions in crime prevention in Norway today: the "Teddy Police" representing social crime prevention, and the $P O P$-stars. These two directions seem very different, and may even appear antagonistic at first. Yet there is no reason why the "Teddy Police" and the POP-stars would not profit greatly by cooperating.

\section{Forebygging hva er det?}

Forebygging av kriminalitet er som mange har påpekt et meget bredt begrep som har en tendens til å omfavne det meste og kan være vanskelig å avgrense (Balchen 2004, Giertsen 1994, Kyvsgaard 1990, Knutsson 1997). Svært mye av hva politiet gjør kan på ett eller annet vis defineres som forebyggende aktivitet. Trafikkontroller, serviceoppgaver, opplysende virksomhet, etterforskning, ordenspatruljering, hjelpeoppdrag, uro-aktivitet, selv typisk reaktive oppdrag relatert til fengsling og påtale kan på et eller annet vis kalles forebyggende aktivitet. Politidirektoratet har i sin strategiplan for kriminalitetsforebygging presentert en slik meget vid definisjon blant flere andre: "En felles aktivitetsform for alle politiaktivitetene, slik at en i sum vil oppnå forebyggende effekt av alt politiarbeidet." (Politidirektoratets Strategiplan $2002-2005$ s. 8) En så vid definisjon er uheldig når det gjør begrepet uhåndterlig og tømt for konkret innehold.

Det er viktig å være klar over at forbygging i norsk politi ikke er noe nytt. Samtidig har innholdet i hva man sikter til med forebygging forandret seg.

Går man 70 - 80 år tilbake i tid så er det tydelig at forebygging innen politiet var knyttet opp mot ordinære ordensoppgaver og håndteringen av straffesaker.

\footnotetext{
* Title in English: Crime Prevention and the Role of the Police. Original in Norwegian.
} 
I Politiinstruksen av 1927 kan man lese at politiet skal: "skride advarende og regulerende inn for å avverge en straffbar handling"

Dette kommer også til uttrykk i Politilovkomiteéns rapport fra 1914 i forbindelse med forarbeidet til Politiloven av 1936 som understreker at ikke bare ordenspolitiet, men også kriminalpolitiet har proaktive oppgaver:

"Kriminalpolitiet er ikke længer indskrænket til at forfølge begaaede forbrytelser og
haardhændt at bringe lovovertrædere til straf. Det paalegger likesaavel som ordensmag-
ten (ordenspolitiet) ogsaa at gripe advarende og regulerende ind og i tilfelle at paakalde
positive foranstaltninger for om mulig at forebygge eller hindre straffbare handlinger"
(Auglend 1991 s. 47).

Denne mer straffesaksrelaterte måten å tenke forebygging lever fortsatt, kanskje særlig blant påtalejuristene (NOU 2004:6). Det oppstod et historisk skille innen forebygging i norsk politi på 1990 tallet. I løpet av dette tiåret fikk politiet klart formaliserte forebyggeroppgaver og forebygging ble for alvor skilt ut som egen tjeneste (NOU 1981:35, St. meld 231991 - 92). Politiloven av 1995 formaliserte dette juridisk.

De første "riktige" forebyggere kom likevel tidligere. Det var polititjenestemenn som vektla de "mykere" mer sosiale sider ved politirollen og som ønsket tettere kontakt til befolkningen, særlig barn og unge. Opprettelsen av Bydelspolitiet i Oslo i 1968 fremheves ofte som viktig. ${ }^{2}$ Det var likevel på 90- tallet at det skjedde en profesjonalisering innen forebygging.

De profesjonelle forebyggere arbeidet det første tiår i stor grad med barn og unge: oppsøkende arbeid, individrettede tiltak og store holdningskampanjer stod sentralt. Det oppstod ulike "forebyggerkulturer" i de politidistriktene hvor det ble opprettet egne forebyggeravdelinger. Trondheim ble de store holdningskampanjenes arnested, derfra kom "Fra bagatell til helvete" og "Det er ikke tøft å være død". Manglerud i Oslo utviklet ekspertise på vanskelige ungdomsgjenger, derfra kom blant annet det indvidrettede tiltaket bekymringssamtalen. Noe av det mest slående med utviklingen av kriminalitetsforebygging i norsk politi er i hvor stor grad enkeltpersoner og enkeltmiljøer har fått utvikle sin egenart. Mye var påvirket av utenlandske ideer, eksempelvis var Kvarterspolisen i Stockholm en viktig inspirasjonskilde for bydelspolitiet, men man utviklet sine egne varianter og mye var særnorsk. Et annet kjennetegn, som for øvrig preger svært mye politiarbeid, er at det var handlingsrettet og sprang ut av behovet "for å gjøre noe", snarere enn fra analyser eller strategiske planer. Svært lite av den forebyggende innsatsen har vært dokumentert gjennom forskning eller evaluering. Det er derfor vanskelig å trekke slutninger om i hvilken grad innsatsen har fungert tilfredstillende. 
Nok en omveltning kom med Politidirektoratets Strategiplan for forebygging i 2002. Denne understreker at forebygging skal foregå ved bruk av problemorientert politiarbeid (POP). Strategiplanen tar forbyggingen fra de "profesjonelle" forebyggerne og flytter den tilbake til å være en sentral del av hele politiets virke. Forebygging skal ikke lenger primært dreie seg om barn- og unge, men omfatte alle former for kriminalitet og ordensforstyrrelser. I følge blant annet Goldstein (1990) så er ikke problemorientert politiarbeid en forebyggermetode i seg selv, men i stedet en arbeidsfilosofi, en måte all politivirksomhet skal drives. POP flytter også blikket fra individer til handlinger, eller identifiserte problemer. Det mest "revolusjonerende" med POP er ikke de ulike tiltakene som iverksettes, men den analytiske og strategiske tilnærmingen til forebygging. Problemorientert politiarbeid stiller krav til politiet at de skal planlegge sin aktivitet ut fra analyser av årsakene til problemene. Det er avgjørende at innsatsen evalueres for at man skal kunne lære av den.

Med strategiplanen har det skjedd en ytterligere avgrensing av forebygging $\mathrm{i}$ politiet. Torstenson og Wickströms definisjon av forebygging er henvist til i flere sentrale dokumenter og oppsummerer i stor grad det bærende perspektivet. POP sammenfaller her i høy grad med det situasjonelle perspektivet.

"Intervention i mekanismer (åtgärder) som påverkar moralbildningen och vardagslivets utforming på ett sådant sätt

(1)att individers benägenhet (tilbøyelighet) att begå brott minskar, eller

(2) att förekomsten av situationer som bidrar til individers motivation att begå brott minskar." (Torstensson og Wikström 1995, s. 17) .

For å illustrere det mangfold av ulike aktiviteter som har blitt og som fortsatt benevnes som forebygging i norsk politi kan følgende skjema gi et vist inntrykk. 
Tabell 1 .

\begin{tabular}{|c|c|c|c|}
\hline Strategi & Virkemiddel & $\begin{array}{l}\text { Idegrunnlag / } \\
\text { politirolle }\end{array}$ & Tidsperiode \\
\hline $\begin{array}{l}\text { Forebygging } \\
\text { gjennom } \\
\text { patruljering og } \\
\text { oppsøkende tjeneste. } \\
\text { Etterforskning og } \\
\text { rettshåndhevelse. }\end{array}$ & $\begin{array}{l}\text { Forhindre at kriminalitet skjer. } \\
\text { Gripe inn overfor uønsket atferd. } \\
\text { Avskrekke ved straff. }\end{array}$ & $\begin{array}{l}\text { Politifaglig og } \\
\text { Strafferettslig logikk. } \\
\text { Hviler på politiets } \\
\text { rett til å bruke makt. }\end{array}$ & $1900-2005$ \\
\hline Bydels og nærpoliti & $\begin{array}{l}\text { Nærhet og gjensidighet til } \\
\text { befolkningen. Samspill. }\end{array}$ & $\begin{array}{l}\text { Politiets "myke" og } \\
\text { sivile sider. Sosialt } \\
\text { engasjement. }\end{array}$ & $1968-2005$ \\
\hline $\begin{array}{l}\text { Politiets } \\
\text { sosialkontor } \\
\text { (NOU 1981:35) }\end{array}$ & $\begin{array}{l}\text { Følger opp "klientenes" sosiale } \\
\text { og helesmessige problemer. }\end{array}$ & $\begin{array}{l}\text { "Formidler" til } \\
\text { hjelpeapparatet } \\
\text { og hjelper. }\end{array}$ & $1900-2005$ \\
\hline $\begin{array}{l}\text { Holdnings- og opp- } \\
\text { lysningskampanjer }\end{array}$ & $\begin{array}{l}\text { "Onkel politi” i skoler, } \\
\text { barnehager og ungdomsklubber. } \\
\text { Bamsen Eddy. } \\
\text { Brede kampanjer: } \\
\text { - ikke tøft å være død. }\end{array}$ & $\begin{array}{l}\text { Politiet som forbilde } \\
\text { og "opplyser". } \\
\text { Bevisstgjøre og } \\
\text { ansvarliggjøre } \\
\left(\mathrm{PKF}^{3}\right) \text {. }\end{array}$ & $1960-2005$ \\
\hline $\begin{array}{l}\text { Person- } \\
\text { individrettede tiltak }\end{array}$ & $\begin{array}{l}\text { Tiltak rettet mot barn og } \\
\text { unge med "risikoatferd". } \\
\text { Eksempler: } \\
\text { bekymringssamtalen og } \\
\text { Exit. }\end{array}$ & $\begin{array}{l}\text { Politiet som } \\
\text { sosialarbeider } \\
\text { og kurator. }\end{array}$ & $1985-2005$ \\
\hline Samarbeidsmodellen & $\begin{array}{l}\text { Formalisert samarbeid } \\
\text { eksempelvis med barnevernet. } \\
\text { Bredere samarbeidsmodeller } \\
\text { som SLT, SSP. }{ }^{4}\end{array}$ & $\begin{array}{l}\text { Politiet er en av flere } \\
\text { etater som arbeider } \\
\text { med forebygging. } \\
\text { Politiet som formidler } \\
\text { til andre etater. }\end{array}$ & $1970-2005$ \\
\hline $\begin{array}{l}\text { Politiets } \\
\text { kriminalvern } \\
\text { (NOU 1981:35) }\end{array}$ & $\begin{array}{l}\text { Rådgiving og veiledning } \\
\text { i bruk av låser, alarmer, } \\
\text { sikringstiltak med mer. }\end{array}$ & $\begin{array}{l}\text { Politiet som } \\
\text { "vaktmester" } \\
\text { og teknikker. }\end{array}$ & $1970-2005$ \\
\hline $\begin{array}{l}\text { Situasjonell } \\
\text { forebygging, } \\
\text { CPTED }\end{array}$ & $\begin{array}{l}\text { A redusere mulighetene } \\
\text { til å begå kriminalitet. }\end{array}$ & $\begin{array}{l}\text { Analytisk,"teknisk", } \\
\text { "planlegger". }\end{array}$ & $1995-2005$ \\
\hline $\begin{array}{l}\text { Problemorientert } \\
\text { politiarbeid } \\
\text { (POP) }\end{array}$ & $\begin{array}{l}\text { Strategisk forebygging. } \\
\text { Organisasjonsperspektiv. } \\
\text { Innsats rettet mot årsakene. } \\
\text { Proaktiv innsats. }\end{array}$ & $\begin{array}{l}\text { "Alle" i etaten } \\
\text { er forebyggere. } \\
\text { Analytisk, strategisk } \\
\text { helhetstenkning. } \\
\text { Samarbeid. }\end{array}$ & $2002-2005$ \\
\hline
\end{tabular}

*Periodiseringen er meget grov. Det er ofte vanskelig å tidsfeste når en strategi dukker opp og tas i bruk. Eksempelvis har forebygging gjennom patruljering en lang historie fra før $1900 \mathrm{og}$ det har blitt undervist i POP ved Politihøgskolen siden 1994. 


\section{Bamsepoliti og POP-stjerner}

Fremstillingen over kan virke avskrekkende i sitt mangfold, men dagens situasjon blant de profesjonelle forebyggere i norsk politi kan, noe satt på spissen, påstås å være delt i to i leire som kan betegnes som "bamsepoliti" og POP.

"Bamsepolitiet" er en noe belastende betegnelse som benyttes innad i politiet. Bakgrunnen er at mange forebyggere som arbeidet med barn og unge benyttet seg av politibamsen Eddy som et pedagogisk virkemiddel. I dag har betegnelsen nærmest blitt synonymt med mykt politiarbeid og oppgaver som mange i etaten ikke oppfatter som "skikkelig" politiarbeid (Granér 2004, Finstad 2000). Min bruk av begrepet "bamsepoliti" er ikke ment negativt, mye av det forebyggende arbeidet særlig rettet mot barn- og unge fortjener honnør og ikke sjikane. Når begrepet benyttes er det fordi det er innarbeidet og assosieres til et spekter av forebyggende aktiviteter. Denne aktiviteten er grunnleggende individorientert, nærhet til ungdomsgruppen understrekes for å fange opp signaler på utvikling av kriminell atferd, derfor anses såkalte risikofaktorer som viktige (PKFs Strategidokument 2004). "Bamsepolitiet" har en grunnleggende sosial profil som ikke nødvendigvis er myk, de vektlegger eksempelvis betydningen av grensesetting og reaktive tiltak. Det er muligens overflødig å nevne, men en av deres viktigste saker er utviklingen av forebygging som eget fagområde og økt profesjonalisering.

Følgende strategier fremheves av politiets kriminalitetsforebyggende forum (PKF) som viktige forebyggerstrategier (Strategidokument s. 4):

- Oppsøkende polititjeneste

- Etterforskning av barne- og ungdomskriminalitet

- Tverretatlig samarbeid

- Holdningsskapende arbeid.

Denne arbeids- og tenkemåten mottar støtte i sentrale deler av Justisdepartementet. PKF og personer knyttet til denne organisasjonen har ved flere anledninger vært sentrale i utformingen av forebyggende strategier og regelverk. ${ }^{6}$

Den andre hovedretningen er problemorientert politiarbeid. Denne er mer analytisk og har en bredere organisasjonsmessig tilnærming til forebygging. POP filosofien understreker at alle fra topp til bunn i politiorganisasjonen skal arbeide proaktivt. Forebygging er ikke forbeholdt et knippe spesialister, men noe alle må ta del i. Politiet skal sette inn tiltak mot identifiserte problemer-ikke individer. Innsatsen bygger på analyser som søker å avdekke årsakene til at man har disse problemene (Balchen 2004). Tiltakene som iverksettes skal rette seg mot årsakene til problemene, ikke symptomene. Samtidig understrekes det at politiet i mange tilfeller ikke er "problemeierne", men at det er andre etater, grupper eller bedrifter 
som har hovedansvar for å gjøre noe med problemet. Dette hviler på erkjennelsen av at politiet i mange tilfeller har tatt på seg oppgaver som verken er deres eller som de har kompetanse til å håndtere: "Samtidig måtte politiet erkjenne at det ikke alltid hadde den beste kompetanse, eller størst potensial til å forebygge eller redusere omfanget av alle former for kriminalitet." (Balchen 2004, s. 10)

I praksis har POP hatt en tendens til å rette seg mot mengdekriminalitet og ordensproblemer som kan identifiseres med politiets dataverktøy. Dette har blant annet medført at flere i de landlige lensmannsdistriktene har oppfattet POP som lite relevant. Deres innvending har vært: "vi har jo ikke mengdekriminalitet". Et savn i de fleste politidistrikter er analysekompetanse. Uten gode analyser har problemorientert politiarbeid lett for å få et preg av å være "keiserens nye klær" og at man iverksetter gamle velprøvde tiltak. Derfor betegnes POP ofte som synonymt med "godt gammeldags politiarbeid".

POP i praksis har en tendens til å forbindes med situasjonelle tiltak. Tiltakene er ofte låste dører eller enkle opplysningskampanjer. Noe av det "skjulte pensum" ved problemorientert politiarbeid rettet mot mengdekriminalitet, ${ }^{7}$ er at kriminalitet består av trivielle handlinger som kan "løses" ved enkle tiltak (Clarke 1997 og Felson 1998).

En fordel med det problemorienterte politiarbeidet fra et ledelsesperspektiv er at man har klare avgrensede mål og at resultatene av innsatsen stort sett lar seg måle på et vis. ${ }^{8}$ Samtidig svikter det nå alvorlig når det gjelder det å måle effekten og å utføre evalueringer av tiltakene. I den grad de har blitt evaluert har dette skjedd lokalt av politiets egne folk og målindikatorene har vanligvis vært om de anmeldte lovbruddene har økt eller avtatt.

Hvis "bamsepolitiet" betegnes som sosialarbeidere så fremstår POP-stjernene mer som teknikere, akademikere og vaktmestere. Det er vansker med å selge inn problemorientert politiarbeid i politiet fordi det forbindes med papir- og kontorarbeid. En politimann gikk så langt at han hevdet at det var umulig å rekruttere noen til å arbeide med analyser om "man ikke ga dem en biljakt i uka".

Mens de profesjonelle forebyggerne har knytninger opp mot Justisdepartementet så er det problemorienterte politiarbeidet forankret i Politidirektoratet. Metoden skal etter strategiplanen fra 2002 være utbredt som arbeidsmetode i norsk politi ved utgangen av 2005. Dit er det fortsatt langt.

\section{Forebygging og politirollen}

En av de mest utbredde mytene om politiet, som også deles av politiet selv, er at deres hovedoppgaver er å fange forbrytere og å bekjempe kriminaliteten. Innad i politiet er det et stående uttrykk at deres målsetning er "flest fanger i bakgården." Dette bør ikke utelukkende oppfattes som ironi. Dette syn preger politiets selv- 
bilde, yrkeskultur og hva de definerer som viktige oppgaver og skikkelig politiarbeid (Finstad 2000 og Granér 2004). På den annen side er det et sentralt funn innen store deler av forskningen at politiets påvirkning på folks lovlydighet og kriminalitetsutviklingen i velfungerende samfunn ofte er helt minimal: "Indeed the police are relatively unimportant in the enforcement of the law." (Banton i Newburn 2005, s. 132).

Politiforskningen viser at politiets ordensoppgaver relatert til kriminalitet kun utgjør en liten del av deres arbeid. I angloamerikanske studier er mellom $15 \mathrm{og}$ 20 prosent av politiets oppringninger relatert til kriminalitet, men mye av dette er bagatellmessig eller oppdrag som knapt kan betegnes som kriminalitet i det hele tatt. I virkeligheten er tallet på henvendelser til politiet relatert til kriminalitet ofte ikke mer enn 7 til 10 prosent (Bayley i Newburn 2005 s. 142). Reiner (2000) påpeker at sannsynligheten for at en politimann skal støte på kriminalitet ved normal patruljering er meget liten. Det er all mulig grunn til å tro at disse tallene er lavere i Norge enn i den angloamerikanske verden (Finstad 2000).

Det er heller ikke slik at politiet er travelt opptatt med å pågribe lovbrytere. I USA hvor politiet nok kan sies å være glad i å pågribe utfører en gjennomsnittlig politimann i ordenstjeneste 19 pågribelser (arrests) i løpet av et år (Bayley i Newburn 2005).

Men hva gjør politiet? Det er i følge mange forfattere slik at politiet ofte "venter på at noe skal skje", mye patruljering er kjedelig og lite dramatisk, relatert til oppdrag som på engelsk kalles "cats-in-a-tree" i Australia "frogs-in-the-drain". I Norge synes en udbredt kveldsaktivitet å være "å lempe fyll". Mye av hva de gjør faller inn under den store sekken servicerelaterte oppgaver.

Politiets har en rolle som går ut på at de tar "alle oppdrag som ingen andre tar". Ordenspolitiet har viktige oppgaver som fleksible problemløsere, fredsbevarere (peace-keepers) og som fredsmegler (peace officer). Bittner sier at politiet tilkalles når man har hendinger av typen "noe-skjer-som-ikke-skulle-skje-og-somnoen-burde-reagere-på-og-gjøre-noe-med" (Bittner i Newburn 2005 s. 162). Deres spesielle kompetanse ligger $\mathrm{i}$ at de har makt som de både har rett og plikt til å benytte når det er påkrevd. "The policeman, and the policeman alone, is equipped, entitled, and required to deal with every exigency in which force have to be used, to meet it." (ibid s. 165).

Publikumsundersøkelser bekrefter mye av det samme som politiforskningen har dokumentert. Det er ofte de ordens og servicerelaterte oppgavene, som politiet selv ikke oppfatter som skikkelig politiarbeid, som etterspørres og som gjør politiet populære. Publikumsundersøkelser viser ofte at det ikke er alvorlig kriminalitet som står høyest på folks ønskeliste til politiet, men å ivareta roen i nabolaget, gjøre noe med bråkete hunder og ordne opp i lokale trafikkforhold. 
Det kan virke noe nedslående på en POP entusiast, at publikum understreker betydningen av at politiet rykker ut når de blir tilkalt. På den annen side kan det oppfattes som positivt at det stort sett er triviell kriminalitet og ordensforstyrrelser som vektlegges, noe situasjonelle tiltak og problemorientert politiarbeid er godt egnet til å takle.

Det kan hevdes at både "bamsepolitiet" og POP-stjernene i for stor grad vektlegger betydningen av kriminalitet. "Bamsepolitiet" overdriver viktigheten av ungdomskriminalitet og troen på egne ferdigheter til å forhindre kriminelle karrierer. De fleste steder i Norge er ikke og vil neppe ungdomskriminalitet bli noe større problem. Ofte mangler en klar rolleforståelse i forhold til hvem som gjør hva med ungdomskriminaliteten. Det kan også synes som man mangler tiltro til andre profesjoners perspektiver og kunnskap når det gjelder innsats rettet mot barn- og unge. ${ }^{9}$

Det har skjedd relativt store endringer i forhold til forretninger og oppgaver politiet skal løse i løpet av de siste tiår. Styringen og organiseringen av etaten har også gjennomgått forandringer (Stenning og Shearing 2005 og Garland 2001). Politiet forventes å takle oppgaver de for to eller tre tiår siden knapt viet oppmerksomhet eller som ble ansett å være andres. Blant politiets prioriterte oppgaver er offerarbeid, familievold, organisert kriminalitet (Trafficking in Women, narkotikasmugling), terrorisme, internasjonalt politiarbeid (opplæring, Civpol innsats, SIS), frykten for kriminalitet, enkeltpersoners sikkerhet, kriminalitetsforebygging, miljøkriminalitet, cybercrime og datakriminalitet for å nevne noen. Politiet skal være serviceorientert og behandle sine "kunder" på en profesjonell måte, noe som ofte måles i "kundeundersøkelser".

De siste tiårene har styringen av politiet fått et preg av moderne managementtenking med målstyring som det store moteordet. Politimestere premieres nå økonomisk etter i hvilken grad de når de målene som er satt. ${ }^{10}$ Med managementideologien og servicepreget følger også et økt behov for informasjonsbehandling, analyser og kommunikasjonsstyring. På toppen av dette ser man at politirollen utfordres ved at grensedragningen overfor den private kontrollnæringen er utydelig. Det samme kan sies om grensen opp mot forsvaret, eksempelvis når det gjelder terrorsime. Det er ikke alltid like tydelig hvem som gjør hva og det skjer en ikke ubetydelig personalmessig utveksling mellom den private kontrollnæring, forsvaret og politiet.

Denne utviklingen gir konsekvenser for det forebyggende arbeidet i politiet. Problemorientert politiarbeid er på mange måter en "tvillingideologi" til målstyringen innen politiet. Den står for en analytisk og målstyrt innsats hvor resultater må synliggjøres, vanligvis i form av tall og statistikk som innen målstyringen.

At denne måten å arbeide forebyggende har kommet i løpet av de siste par tiår er ingen tilfeldighet. Metoden er godt egnet til å takle mange av de nye oppgavene som krever spesialkunnskap politiet ofte ikke besitter. Den analytiske 
tilnærmingen som ligger i problemorientert politiarbeid er den samme eller svært lik eksempelvis "intelligence-led", "evidence-based" eller kunnskapsstyrt politiinnsats som det kalles i Norge. ${ }^{11}$

"Bamsepolitiet" ligger dårligere an når det gjelder målbarheten av deres arbeid. De rammes lett av påstander om at det mangler dokumentasjon av effekten av hva de gjør. Det er mulig deres forebyggende innsats "fungerer". Problemet er at det i liten grad har vært målt, slik at man strengt tatt ikke vet hva som virker eller ikke virker og under hvilke omstendigheter. "Bamsepolitiet" kritiseres tidvis fordi mange av dens oppgaver er sosialarbeid som bør overlates til de "profesjonelle" sosialarbeiderne. I dette ligger det implisitt en oppfatning av hva politirollen er og bør være som langt fra deles av alle i eller utenfor politiet.

Problemorientert politiarbeid er ikke en metode eller noen rolle. I stedet er det, hva Balchen (2004) kaller en arbeidsfilosofi eller mal for hvordan man skal arbeide målrettet og analytisk. Tiltakene som iverksettes kan dekke de fleste formene for forebygging beskrevet i den tidligere oversikten (tab.1). Man kan utmerket godt bruke sosialforebyggende tiltak eller ulike former for samarbeide innen rammen av POP, det trenger ikke være situasjonelle eller tekniske løsninger (Politidirektoratet 2002). Dette betyr at forebyggende tiltak rettet mot barn og unge utmerket godt kan utføres av "bamsepoliti" med sosiale tilnæring innen rammen av POP. ${ }^{12}$ Mye tyder på at de to sakte begynner å nærme seg hverandre. Det bør de også. "Bamsepolitiet" har mye å tilføre POPen og motsatt. De har ofte en god kunnskap om hva som skjer i ungdomsmiljøene, de har et bredt nettverk og samarbeider med en rekke ulike etater og grupper, skole, barnevern og sosialtjenesten for å nevne noen. De har en nærhet til samfunnet og kan dekke flere etterspurte servicefunksjoner. De gir politiet et ansikt utad og en bredere kontaktflate mot både unge og voksne. Samtidig har de opparbeidet en fagkunnskap innen ulike felter som er en viktig ressurs. På den annen side vil de tjene på å arbeide mer analytisk og systematisk. Det viktigste er at "bamsepolitiet" i større grad søker å måle og synliggjøre effekten av hva de gjør. Det skader heller ikke at de flytter noe av perspektivet fra enkeltindivider og risikofaktorer i retning av lovbrudd og handlinger, de vil uansett finne at disse begås av en relativt begrenset gruppe unge menn.

En fare ved den problemorienterte tilnærmingen er at den ender opp med å bli assosiert med situasjonelle tekniske løsninger og mengdekriminalitet. ${ }^{13}$ Dette vil gjøre at man mange steder vil føle at denne tilnærmingen har lite å gi dem, siden de ved flere lensmannskontor knapt har registrert kriminalitet. Det tekniske, noe administrative preg ved den problemorienterte metoden kan mykes opp ved at profesjonelle forebyggere blir tiltakenes ansikt utad, ved at deres kompetanse benyttes aktivt når det gjelder å opprette kontakter og samarbeide med forebyggende tiltak. 


\section{Referanser:}

Auglend, Ragnar L: "Utkast til ny lov om politiet med motiver", Stensil, Justisdepartementet, Oslo, 1991.

Balchen, Paal Christian: "Innføring i problemorientert politiarbeid", Politidirektoratet, 2004.

Banton, Michael: "The police as peace officers" i Tim Newburn (ed): Policing. Key Readings, Wilan Publishing, 2005.

Bayley, David H: "What do the police do?" i Tim Newburn (ed): Policing. Key Readings, Wilan Publishing, 2005.

Bittner, Egon: "Florence Nightingale in the pursuit of Willie Sutton, a theory of the police" i Tim Newburn (ed): Policing. Key Readings, Wilan Publishing, 2005.

Clarke, Ronald B: "Situationell brottsprevention", BRÅ, Stockholm, 1997.

Felson, Marcus: "Crime \& Everyday Life", Pine forge press, 1998.

Finstad, Liv: "Politiblikket", Pax forlag, Oslo, 2000.

Fokus, Fagbladet for politiets kriminalitetsforebyggende forum (PKF), leder, nr. 2, 2004.

Garland, David: "The Culture of Control. Crime and Social Order in Contemporary Society", The University of Chicago Press, 2001.

Giertsen, Hedda: "Forebygging av kriminalitet. Alt for bredt og alt for smalt.", Nordisk tidsskrift for kriminalvidenskab, nr. 3, 1994.

Goldstein, Herman: "Problem - Oriented Policing", McGraw-Hill, New York, 1990.

Granér, Rolf: "Patrullerande polisers yrkeskultur", Lund Dissertations in Social Work, 2004.

Høgetveit, Einar: "ØKOKRIMs strategi mot økonomisk kriminalitet”, i Larsson og Myklebust (red): Organisert og økonomisk kriminalitet - myter og realiteter, PHS forskning nr. 2, 2004.

Knutsson, Johannes: "Kriminalitetsforebygging $i$ et situasjonelt perspektiv", Politihøgskolen, Oslo, 1997

Kyvsgaard, Britta: "Er ledigang roden til alt ondt?", Kriminalistisk institutt, København, 1990. "SSP og forebyggelse av børne- og ungdomskriminalitet" i Kyvsgaard, Snare og Wilhjelm (red): Forebyggelsens veje og vildveje, Kriminalistisk instituts stencilserie $\mathrm{nr} 58,1990 \mathrm{~b}$.

Larsson, Paul og Trond Myklebust (red): "Organisert og økonomisk kriminalitet - myter og realiteter", PHS forskning nr. 2, 2004.

NOU 1981:35 "Politiets rolle $i$ samfunnet".

NOU 2004:6 "Mellom effektivitet og personvern. Politiarbeid i forebyggende øyemed."

Politidirektoratet (2002) Strategiplan for forebyggende politiarbeid 2002 - 2005.

Politiets kriminalitetsforebyggende forum, Strategidokument, 2004.

Reiner, Robert: "The Politics of the Police", Sage, third edition, 2000.

Stenning, Philip and Clifford Shearing: "Reforming police - opportunities, drivers and challenges", manus, 2005.

St. meld. Nr. $231991-92$. Om bekjempelse av kriminalitet.

Torstensson, Marie og Per-Olof Wickström: "Brottsprevention och problemorienterat polisarbete.", Rikspolisstyrelsen, Stockholm, 1995. 


\section{Noter:}

1 En stor takk til Erling Børstad i Politidirektoratet for inspirasjon og historisk kunnskap.

2 Børstad (i intervju) fremhever knytningen mellom enkeltpersoner og den sosiale tilnærming som sto bak politiets badeturer for vanskeligstilte barn på 1950 tallet og de idealer som ble bærende i utviklingen av bydelspolitiet.

3 PKF er forkortelse for Politiets Kriminalitetsforebyggende Forum som er interesseorganisasjonen for forebyggere innen politiet.

4 SLT står for Samordning av lokale kriminalitetsforebyggende tiltak og er en av Det kriminalitetsforebyggende råds (KRÅD) store satsinger, mens SSP står for samarbeid mellom skole- og fritidsforvaltningen, sosial - og sunnhetsforvaltningen og politi og er en dansk modell som også har vært utprøvd i Norge (Kyvsgaard 1990b).

5 Dette er selvsagt forenklet. De strafferettslige perspektiver med vektlegging av almen- og individualpreventive virkninger, men også betydningen av å kunne foregripe kriminelle handlinger lever i beste velgående, særlig hos Riksadvokaten og påtalejuristene (Høgetveit 2004 og NOU 2004:6). Flere søker dessuten å forene POPen med det tradisjonelle individrettede arbeidet mot barn- og unge.

6 Blant annet ble bekymringssamtalen innført som en del av politilovens $\S 13$ i 2003.

7 Det typiske er bilinnbrudd, lommetyverier, vold på offentlig sted, forsøpling og ordensforstyrrelser (fyllebråk). Oppgaver som kanskje kan virke trivielle, men som utgjør en stor del av de oppgaver politiet mottar. I praksis kan POP benyttes som arbeidsmetodikk overfor alle oppgaver politiet utfører.

8 Spørsmålet om målbarhet av innsatsen er som flere har påpekt ikke enkelt. Dette særlig når det gjelder i hvilken grad det er politiets tiltak eller andre forhold som påvirker tallenes utvikling, om de reflekterer reell økning eller reduksjon, i hvilken grad det skjer omfordelingseffekter med mer. Min påstand er likevel at denne måten å arbeide forebyggende på medfører langt større muligheter til å kunne måle effekten av tiltakene fordi de er mer målrettede og dessuten skal hvile på analytisk forkunnskap om problemet man setter inn ressurser mot.

9 Dette er ikke et særkjennetegn for bamsepolitiet, men for deler av politiet som har hatt en tendens til å oppfatte eksempelvis barnevernet som unnfallende i forhold til problembarn.

10 Noe enkelt kan en nok si at norsk politi i dag styres etter tanken om "mer og bedre politi for pengene."

11 Problemet her er selvsagt at det ikke eksisterer noen enhetlig eller klar forståelse av hva disse begrepene betyr. Jeg har hittil ikke møtt noen som har kunnet fortelle meg på en grei måte hva kunnskapsstyrt eller etterretningsstyrt politiarbeid betyr.

12 Det synes klart at det også går i denne retning i Norge, se for eksempel leder i Fouks nr. 2 - 2004.

13 Det er mange andre farer hvor jeg kun skal nevne en her og det er at forebygging reduseres til kun tradisjonelle lovbrudd, mens økonomisk-, miljø- og organisert kriminalitet ofte glemmes (se Larsson og Myklebust 2004).

\section{Adresse:}

Politihøgskolen, PB 5027

Majorstuen

NO-0369 Oslo 